[激粉科学 (J.Jpn.Soc. Starch Sci.) 第 34 巻 第 3 号 p.179 185 (1987)]

\title{
㨶き方別扩よび添加物別の餅の物性 ${ }^{\top}$
}

\author{
永島伸浩*，川端晶子*，中村道徳**
}

（昭和 61 年 8 月 18 日受理）

\author{
Physicochemical Properties of "Mochi" Prepared by Various \\ Methods and with Various Additives \\ ("Mochi"-A Traditional Japanese Food. Part 1) \\ Nobuhiro NAGAShima,* Akiko KaWABAta* and Michinori NAKAmURA** \\ * Department of Nutrition, Faculty of Agriculture, Tokyo University of Agriculture \\ (1-1-1, Sakuragaoka, Setagaya-ku, Tokyo 156, Japan) \\ ** Nodai Research Institute, Tokyo University of Agriculture \\ (1-1-1, Sakuragaoka, Setagaya-ku, Tokyo 156, Japan)
}

To investigate the physicochemical properties of Mochi, some were prepared using several preparative methods and with various additives. The texture of the Mochi was observed under a scanning electron microscope and the degree of gelatinization and some physical properties were measured. Mochi, prepared with a pounding type or stamping type machine, exhibited much of the initial rice grain structure, while, ones prepared with a mixer type machine were composed of a well smashed paste form rather than rice grain tissue. The changes in the degree of gelatinization during storage were determined using the $\beta$-amylase and pullulanase method, and only a slight decrease was observed. The physical properties of Mochi, prepared by the three methods, were measured using a rheolometer, a meatshear meter and an extensograph. Mochi prepared with the stamping type machine showed the greatest resistance to extension, and those prepared with the pounding type machine showed the greatest shearing strength. The ones prepared with the mixer type machine showed the minimum hardness and the lowest resistance to extension, and required the lowest shearing strength. The physical properties of three types of Mochi, made with $100 \%$ glutinous rice, $70 \%$ glutinous rice $+30 \%$ waxycorn starch and $70 \%$ glutinous rice $+30 \%$ cassava starch, respectively, were compared. The Mochi containing waxycorn starch were tender, and required a lower shearing strength, while those containing cassava starch showed increases in hardness and adhesiveness.

伝統食品としての餅は，糯米を四水させ䓏籠(せいろ) にて蒝気で蒸し上げたのち，木製めるいは石製の日に入 れ，木製の杵で搗くといら，米の加工品としては簡単な 操作でっくられている，そして，その歴史は古く，奈良 朝時代炕すで存在していたといわれる1,2。

しかし，その加工技術の多くは秘伝，家伝という闒鎖

$\dagger$ 䬼の食品学的研究（第 1 報）

* 東京農業大学農学部栄盖学科, (156 東京都世田谷区 桜丘 1-1-1)

** 東京農業大学総合师究所 (156 東京都世田谷区兴丘 1-1-1)
的な姿で受け䋠がれてきたこと，試料としての䬺が扱い にくいこと，艺して適当な測定機器がなかったことなど の理由から研究も少なく, 米菓製法の一部としての餅の 性質索报った斎藤ら ${ }^{3 \sim 10}$ の報告や糯米の加工利用の中で 餅の品質について柳瀬ら ${ }^{11,122}$ の報告, さら飞, 餅の組織 について桐㴊 ${ }^{13}$ が, 委た, 白玉餅の性質について斎藤

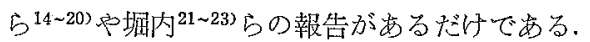

また，最近では，餅の調製法の変化や原料として糯米

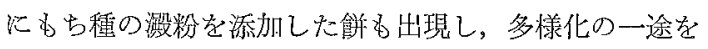
たどっている，そこで，著者らは餅を食品学的見地より， 系統だてて研究することを目的として，本報では搗き方 
別および添加物別傜餅を調製し，いくつかの理化学的性 質を険討した。

\section{実験 方法}

\section{1. 試料}

糯米 (Oryza sativa L. var glutinosa Matsum.) は

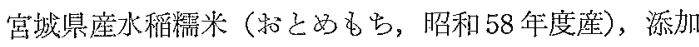
物として，ワキシーコーン(Zea Mays L.) 晸粉（米国 産ワキシーコーンより日本食品化工湖で調製）牤よびキ ヤッサバ .(Manihot esqulenta Crantz) 澱粉（タイ国産 キャッサバより現地味の素(條で調製)をとれぞれ用いた。

\section{2。餅の調製法}

精白燸米 $1400 \mathrm{~g}$ を洗浄後, $20^{\circ} \mathrm{C}$ の恒温器にて 3 時間 吸水させ，電動餅搗き機（日立製 HM-18 型）にて水 $500 \mathrm{ml}$ を入れ，33〜35 分間蒸し上げたの号，下記の公れ ぞれの方式の餅を調製し; 電子ジャ一（像印 TYS -1500 型）に入れ，温度を一定にしたのち，測定に供した。

\section{1）搗き方別餅の調製}

杵搗き式の餅は，市貶の木製の日と杵を用いて一定の 高さより 10 分間 (回数として 140 回) 捣さ上げ，スタン プ式の餅は石曰䑾電動餅捣き機（三ツ星印製作所㑛製, 35 回/分搗き）を用い，途中 4 回機械を止めて餅生地を まとめる操作を加光て，合計 10 分間化約 170 回搗き上 げ，そしてミキサー式の餅性，電動立て羽根式餅搗さ機 （日立製 HM-18 㤠）により10分間搗さ上㓠た。な特， 餅の水分量を同一飞与るため，杵搗き，スタンプ式とも 比打ち水は用いなかった。

\section{2）添加物別の餅の調製}

予備実験の結果, 添加する激粉量は糯米 7 亿対して添 加紧粉量 $3(\mathrm{w} / \mathrm{w})$ としたとさが，良灯な品質の餅が得 られ，㖫好性も高かったので以下この配合比とした。す なわち、ワキンーコーン拈よびキャッサバ濒粉を無水物 換算し, 激粉重量の 1.2 倍の水を加光, 30 分間吸水膨潤 させ， $90^{\circ} \mathrm{C}$ の湯煎を用いて $120 \mathrm{rpm} の$ 速度で溉汼を続 けながら，試料が $80^{\circ} \mathrm{C}$ 亿なるをで予備加熱し，試料を ガラス製シャーレ（直径 $22.5 \mathrm{~cm} \times$ 高さ $5 \mathrm{~cm}$ ) 飞移し, 高さを $2 \mathrm{~cm}$ になるよらにンート状に調製し、スチーム オーブンレンジ（三菱電機製 RO-3700 型）を用い，飽 和水蒸気下で 20 分間加熱糊化させた。として電子レン ジ (東芝製 ER-613S 型) 飞て蒸糯米（水分含量 $44 \%$ ) と同一水分量飞なるまで敗粉ペーストの水分含量を調製 し，これを蒸糯米 $70 \%$ に対し $30 \%$ 添加し，1）と同じス タンブ式の餅を調製した。な物キャッサバ淑粉を用いた 理由は，アミロース含量が 17〜19\%あるにもかかわら
ずアミロペクチンのみからなるもら種の滶粉と近似し

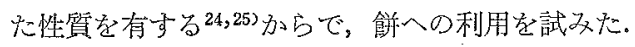

\section{3）測定方法}

(1) 走査型電子顕微鏡 (SEM) による糯米特よび餅の 組織構造の観察試料をグルタルアルデヒド・オスミ ウム酸で二重固定させ，エチルアルコールルて脱水後， 酰酸イソアミルルて置換さ吃, 臨界点乾燥ののち, 金パ ラジウムイオンスパッターにて蒸着させ, 走査型電子顕 微鏡 (日本電子製 JSM-35 型) 、て観察した。

(2) ファリノグラフ 26,277 以る蒸灀米拈よび各潵粉ペ ースト添加蒸糯米の物性測定 ファリノグラフ (Brabender 社製）にてミキサー部はステンレス製 $50 \mathrm{~g}$ 容を 使用し, 予備実験の結果より試料の全量を $28 \mathrm{~g}$ とし, 蒸糯米 $100 \%$ （水分含量 $44 \%$ ）呿よび蒸糯米 $70 \%$ に対 し各筂粉ペースト $30 \%$ (蒸糯米之同水分量汇調製)を添 加した場合の $30^{\circ} \mathrm{C}$ に括汸るファリノグラムを测定し， 常法汇より解析した。

(3) 餅の糊化度の測定 $\beta$-アミラーゼ・プルラナー

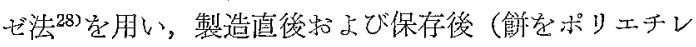
ン製袋に入れ，ヒートシールしたものを $5^{\circ} \mathrm{C}$ の恒温器に 入れ，所定の時間束で保存）の餅について，無水エチル アルコール呿よびアセトンを用いて脱水乾燥さ也, 粉末 試料としたのち，測定した。

(4) レオロメーターKよる餅のテクスチャーの測定 調製後の餅をただちにステンレス製ンャーレ(内径 58 $\mathrm{mm}$, 高さ $18 \mathrm{~mm}$ ) 飞 $15 \mathrm{~mm}$ の高さになるよらに慨を 流し入れ，蓋をし，ポリェチレン製袋に入れてとートシ ールし, 密封後 $5{ }^{\circ} \mathrm{C}$ 飞調製した恒温器に入れ, 各時間ご とヒレオロメーター（飯尾電機製 RMT-1300 型）にて, 運動速度 12 サイクル/分, 運動回数 2 回, 感度 $5 \mathrm{~V}$, 感 珐軸（アクリル製）直径 $18 \mathrm{~mm}$, クリアランス $2 \mathrm{~mm}$, テャート速度 $1500 \mathrm{~mm} /$ 分で測定した。な敊，凝集性の 測定時には陚料表面をポリシートで覆い，付着の影響を 避けた，特性值は常法に上り解析し求めた。

(5) ミートシャーメーターKよる餅の剪断強度の測 定調製後の餅をテフロン製シートと麺棒で，15 mm の厚さに伸ばし，ステンレス製型抜き器（直径 $55 \mathrm{~mm}$ ) でくり抜き，ミートシャーメーター (G. R. Electric 社 製）により剪断強度の測定を行った。委た，保存後の測 定には，乾燥を防ぐために(4)と同じようにステンレス製 シャーレに入れ，蓋をし，ポリエチレン製袋に入れと一 トシールしたのち，5ㄷ の恒温器に入れ，所定の時間ご とに測定した。

(6) エクステンソグラフ ${ }^{29}$ とよる餅の物性の測定 


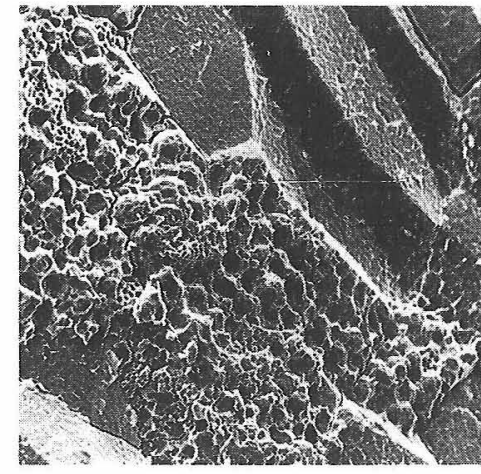

生 米

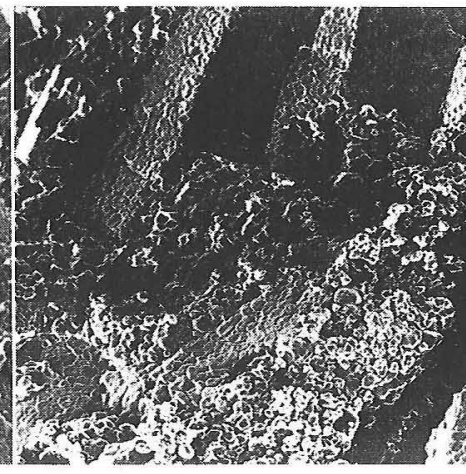

浸 漬 米

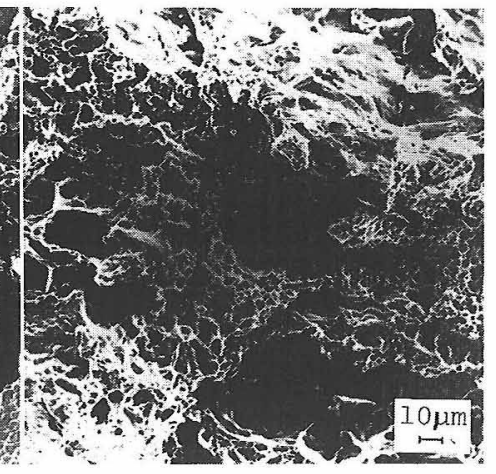

蒸 米

図 1. 糯米の走査型電子顕微鏡写真

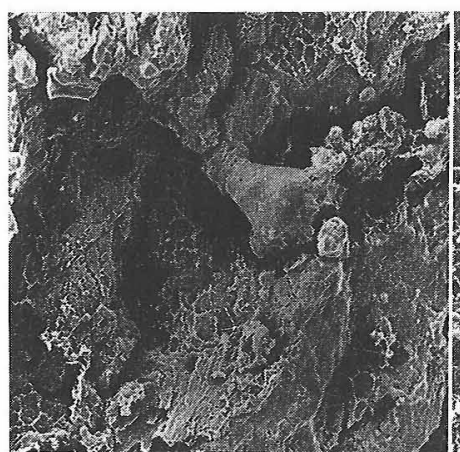

杵搗き

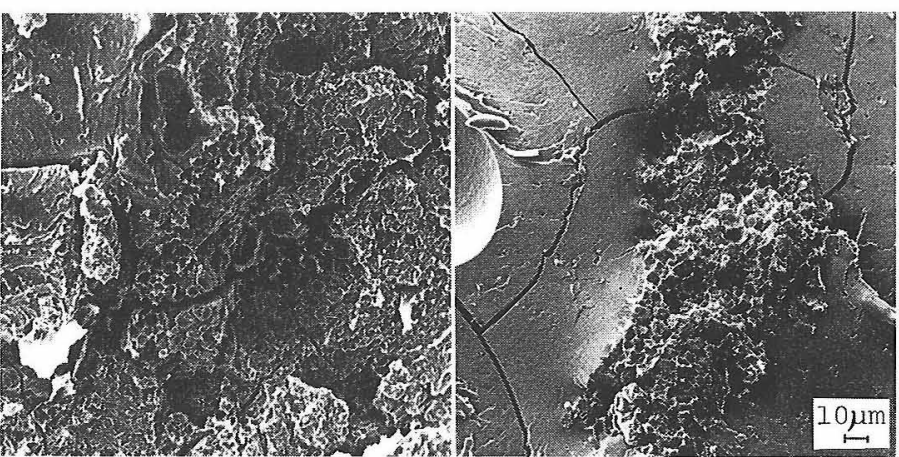

スタンンプ

ミキサー

図 2. 㨶き方別餅の走查型電子顕微鏡写真

調製後の鉡をステンレス製バットに流し入れ，ポリエチ レン製袋に入れ，ヒートンールし，5ㄷ した試料を $10 \mathrm{~mm}$ 角 $\times 155 \mathrm{~mm}$ 長さに調製し、ラップ したのち，2-2）で用いた電子レンジにて 20 秒間再加熱 を行い，陚料の内部温度を $40^{\circ} \mathrm{C}$ までゲ，エクステン ソグラフ (Brabender 社製) のクランプホルダーにはさ み込み，ただらに測定した。

\section{実験 結 果}

\section{1. 走査型電子顕微鏡（SEM）による組織構造}

糯米のSEM 像を図 1 に示した，糯米を繸に割断した わので, 左より生米, 水浸漬米, 蒸米で少る。桐㴊133 述べているように，糯米の生は一つの細胞が澱粉粒の集 団の細長い鉛筆状の柱状構造をして捛り，この細胞が並 んで米の胚乳部を構成している，そして細胞の中の一つ がアミロプラストと呼ばれ，この中に数個から数十個の

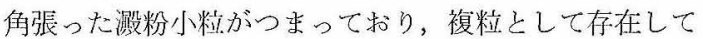

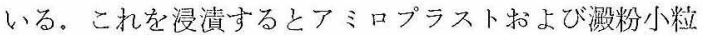

は四水膨閵し，角の部分が丸みを带びてくる。ささらに蒸 すことにより，柱状構造の一部はこわれ，ペースト状の ものが観察される。

搗き方別の慨のSEM 像の 1 例を図 2 亿示した。餅は きわめて複雑な構造をして㧍り，いずれの方式で搗い な䬺もかなりの視野を観察しなければならないが，その 構造の傾向としては，杵搗き式拉よびスタンプ式は此 較的糯米組織の残存部分が多く，また，この残存組織 部の大きさが大さいこと，ミキサー式ではこの残存組織 部の大ささが比較的小さく，乙かもベースト状の部分や 気泡羽多いことが钼察され，この雨者の違いが物性に大 きく影響するものと考兄られる。な拈，激粉ペーストを 添加した餅は糯米 $100 \%$ の䬶之判別が難しく，光学顕微 鏡などを用い，さらに低倍率で観察し検討したいと考克 ている.

\section{2.ファリノグラフによる特性}

蒸糯米抢よび各晸粉ペース卜源加蒸糯米のファリノグ ラムを図 3 に示した、いずれも，ミキシング開始より 3 


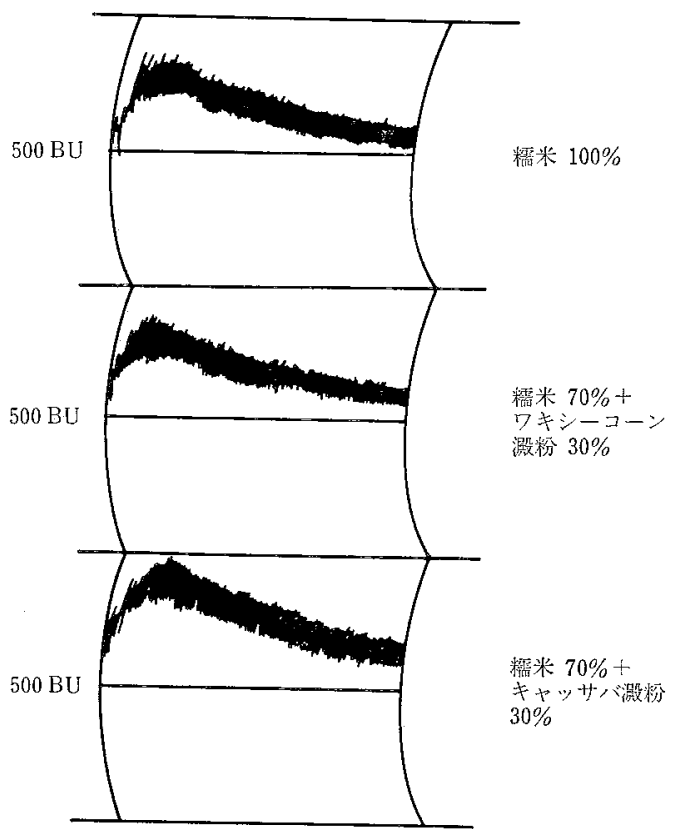

図 3. 添加物餅のファリノグラム

分前後で最高硬粘度を示し，糯米 $100 \%$ が 760 BU，ワ キシーコーン澱粉入り糯米が $780 \mathrm{BU}$ ，キャッサバ踥粉 入り糯米が 890 BU であり，濒粉ペース卜添加に上り， 最高硬粘度が上䒜する傾向が認められたが，キャッサバ 測粉入り糯米に执いて，上昇率が顕著であった。

\section{3. 餅の糊化度の変化}

餅の糊化度の測定結果を表 1 に示した。調製值後（0 時間）の餅は搗き方別，添加物別老問わず $96 \%$ 以上の かなり高い糊化度を示し，冷蔵 $\left(5^{\circ} \mathrm{C}\right) 24$ 時間後ではや や低下の傾问がみられ，また，㨶さ方別ではミキサー式 が，添加物別では濒粉ペース卜添加により糊化度の減少

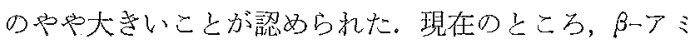
ラーゼ・プルラナーゼ法 ${ }^{28)}$ は糊化激粉が老化していく変 化を追跡する場合，鋭敏にとら光ることができる万法で
めり，斎藤らのジアスターゼ法による凔の糊化度の測 定3)で，ほとんど変化がなかったとの報告に対し，本笑

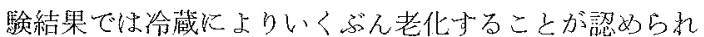
た。しかし，餅がとくに冷蔵保存により，急激に硬化し ていく物性の変化の要因は, 測粉の老化だけでは解決で きない間題であり，今後さらに検討したいと考光ている，

\section{4. レオロメーターによる餅のテクスチャー}

レオロメーターによる餅のテクスチャーの測定結果を 図 4 K示した。硬さと粘りについては，保存時間ととる に増加する傾向に㐫るが，搗さ方別餅の硬さのらち， キサー式の餅が調製直後は杵㨶さやスタンプ式の餅に比 ベて低い值であった。しかし，保存 3 時間では逆にいら ばん高く，興味ある変化を示した。史た，添加物別餙で は，ワキシーコーン激粉添加により餅は柔らかくなり， キャッサバ澱粉添加により，便さと粘りが增加すること が認められた。

\section{5. ミートシャーメーターによる餅の剪断強度}

餅の剪断強度の測定結果を図 5 に示した、糯米 $100 \%$ のミキサー式を除いて，いずれ为調製直後の餅は，やや 大きい剪断強度を示しているが，保存 3 時間でやや餅が 硬化して剪断しやすくなり，測定值は一睹低下寸るが， 保存 24 時間では餅の硬化がさらに進み，煎断に要する 力が大きくなることを示している。糯米 $100 \%$ のキサ 一式餅が，調製直後では剪断強度が試料中もっと为小さ いのに対し, 保存 24 時間ではこの值が逆点し, 図 4 のミ キサー式餅のテクスチャー特性值のららの便さの变化の 傾向と一致することが認められた。 また，添加物別餅で は測粉ペースト添加により，調製直後抏よび保存 24 時 間で，糯米 $100 \%$ 餅の剪断強度を上回り，図 3 のファ リノグラフィの結果と同様な傾向を示した。

\section{6. エクステンソグラフによる物性}

図6に，餅のエクステンソグラムの解析図を，表 2 K, 各試料（餅）のエクステンソグラム特性值を示しだ。エ クステンソグラフは，一定の硬さの小琶粉生地の伸張度

表 1. 郎の糊化度a) の変化

\begin{tabular}{|c|c|c|c|c|c|}
\hline \multirow{2}{*}{$\begin{array}{c}\text { 保存時間 } \\
\left(5^{\circ} \mathrm{C}\right)\end{array}$} & \multicolumn{3}{|c|}{ 搗き方别（糯米 $100 \%$ ） } & \multicolumn{2}{|c|}{ 添加物別(揚き方：スタンプ式) $(\%)$} \\
\hline & 杵 搗 き & ミキサ一 & スタンプ & 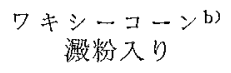 & 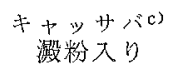 \\
\hline 0 & 98.6 & 97.8 & 99.8 & 97.5 & 96.2 \\
\hline 3 & 96.5 & 89.8 & 98.2 & 88.9 & 92.3 \\
\hline 24 & 92.5 & 87.1 & 96.5 & 85.6 & 89.7 \\
\hline
\end{tabular}

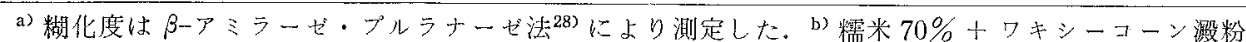

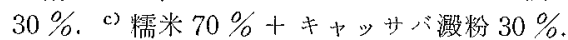


搗き扮别
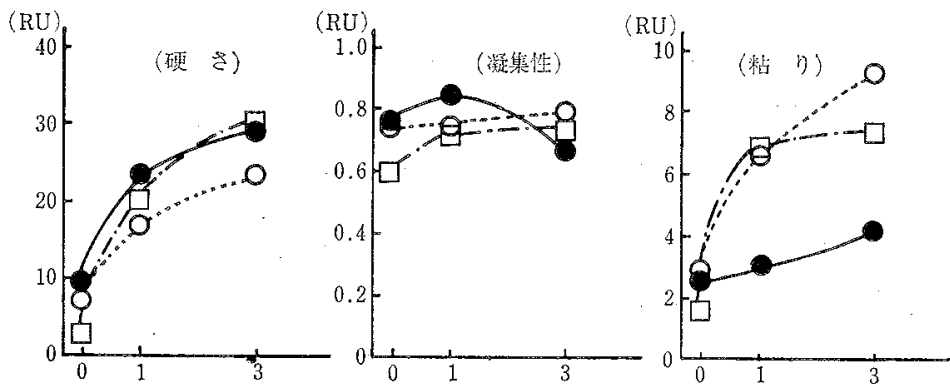

(持脂)

添詶物别
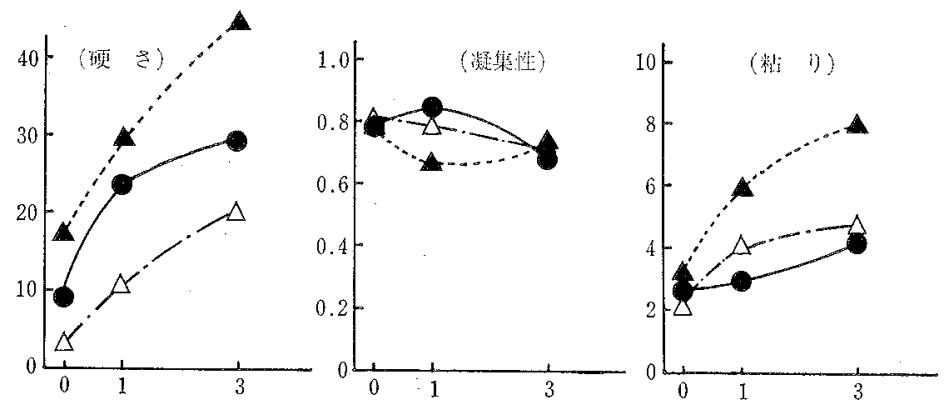

〈淙: 阙)

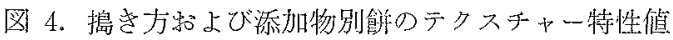

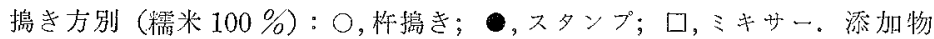

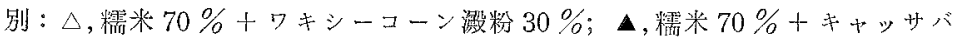
澱粉 $30 \%$.

扰よび抗張力を測定する目的で開発された㙨器で，小考 粉やパン生地の品質判定に広く用いられ，生地の内部的 エネルギーの時間的変化をエクステンソグラムとして自 記させるものである。

解析方法 ${ }^{29}$ は，図60中でAは面積を表わし，この数 字が大きい压と，小麦粉の製パン性が高いとされている。 R核記録カーブの高さ，与なわり，伸長抵抗表表わし， 数值が大きいほど，強鞄で引き伸ばすのに力を要すると されている，Eはカーブの底辺の長さ。古なわら，俳張 度を表わし，長い汪ど，伸びやすいとされている。そし て，伸長抵抗を伸張度で除した值を形状係数と定義して いるが，これはいわゆる「だれ」を表わし，小さいほど， その生地梳れやすい傾向にあるといらことができる。 これらの考え方を本実験では餅生地灾用し，それぞれ の餅の性質の傾向を少るらえでの参考とした。すなわら， 搗き方別では，スタンプ式餅がカーブの面積，高さとも にいらばん大きく，逆にミキサー式䬼がいらばん小さく，
杵搗き式餅がその中間で，スタンプ>杵搗き>ミキサー 式の順に餅を引き伸ばして切れるまでの抵抗性が変化す ることを示して括り，これは図 2 の製造直後のテクスチ ヤ一特性值の硬さの順と一致している。ミキサー式餅は Eがもっとも長く， Rがもっと舟低いことから，餅を引 き伸ばすのに力をかけずに，しかも伸びたのち，切机に くい傾向であることが示された。おた，添加物別餅では， ワキシーコーン溊粉入り餅はEが長く，餅生地を引き伸 姑しやすく，しか当切れにくいことが，キャッサバ測粉 入り䬼はAの面積和よびRが他の䬼よりもかなり大きく， 餅を引き伸ばす際の抵抗の大きいことが認められた。

\section{考察}

\section{1. 餅の組織と糊化度の関係}

杵搗さ括よびスタンプ式の餅火比べ，ミキサー式の餅 の糊化度は保存 24 時間後でやや低い值となった。この ことは，ミキサー式の飭の場合，米稙組織が細かく砕か 
れることにより，アミロプラスト内から流出した糊化測 粉ペーストが多量に餅生地組織の中に充満し，しか子生 地を練り上げる際に空気を多く抱さ込さため，気泡の数 るかなり多くなっている。これに刘し杵搗き式やスタン プ式の餅の場合，米粒組織がかなり残存し，その面積も 大きい、すなわら，アミロプラスト内から流出する澱粉 ペーストの量はミキサー式に比べ少なく, 細胞外に流出 してこない糊化滧粉るかなりあると思われる。これらの 組織の相造が両者の糊化度の違いに影響を及ぼしている

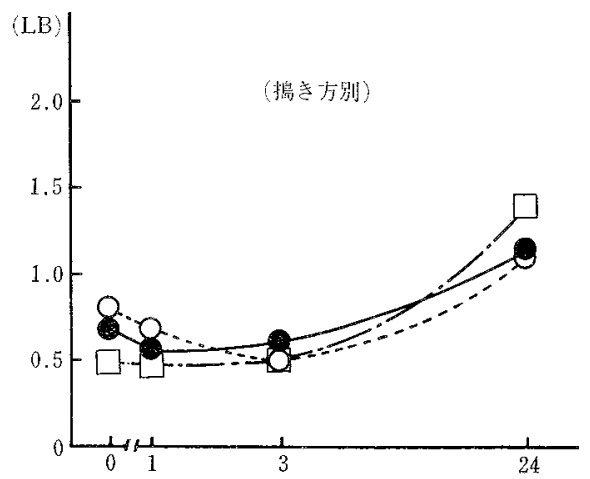

(㬨 䦌)

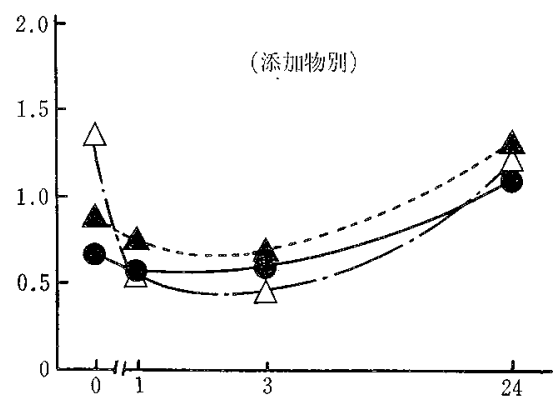

(跱 間)

図 5.㨶さ方扣よび添加物別餅の剪断力

搗き方别 (糯米 $100 \%$ ): ○, 杵揬き; ・ スタンプ;

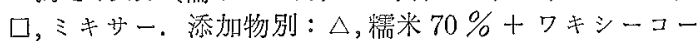

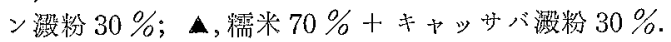

と考学る、スタンプ式炕よるワキシーコーンおよびキャ ッサバ督粉ペースト添加餅の糊化度が，保存することに より糯米 $100 \%$ の餅より低下する傾向にあるのは，ミキ サー式と同様な考方方から餅生地中に存在する激粉ペー ストの割合が多いためと考允られる。江川ら ${ }^{30}$ は溶媒を 用いて餅生地中の澱粉の膨潤崩壞の程度と沈殿画分の量 について調べているが，今後これらの画分と糊化度との 関係についてさらに検討したいと考えている.

\section{2。餅の組織と物性との関係}

冷截保存によっていずれの餅も硬化していく傾向にあ るが，搗き方によって硬化の度合を異にしている。斎 藤 ${ }^{31)}$ や桐㴊 ${ }^{133}$ は餅の物性の要因について，米粒の主成分 である濒粉（アミロペクチン）や蛋白質の単なる集合体 では説明がつかず，米粒組織片とアミロプラスト内より 流出した測粉ペースト和よび気泡の 3 要素が関係してい ると考觉ている。著者らの SEM による餅生地の観察に おいても搗き方により餅の組織構造が異なることが明ら かとなったが，保存過程での組織構造の変化はほとんど 認められず，組織より考察することは困難であった。し かし，糊化度のところで述べたように杵搗き物よびスタ ンプ式とミキサー式では，䂝存米粒片の中以ある淑粉ぺ ーストと米粒細胞内のアミロプラストより流出した莎粉

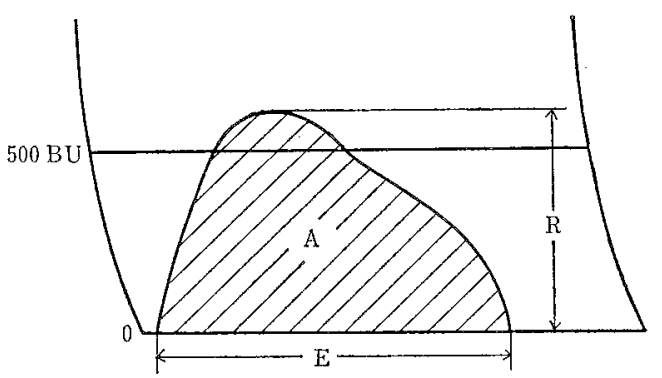

図 6。エクスデンソグラムの解析図

$\mathrm{A}$ : 面積 $(\mathrm{cm}), \mathrm{E}$ ：伸張度 $(\mathrm{mm}), \mathrm{R}$ ：伸張抵抗 (BU), R/E: 形状係数.

表 2。餅生地のエクステンソグラム特性值

\begin{tabular}{|c|c|c|c|c|c|}
\hline & \multicolumn{3}{|c|}{ 搗き方（糯米 $100 \%$ ) } & \multicolumn{2}{|c|}{ 添加物別(㨶き方：スタンプ式) } \\
\hline & 杵 搗き & ミキサー & スタンプ & $\begin{array}{c}\text { ワキシーコーン } \\
\text { 檓粉大り }\end{array}$ & $\begin{array}{l}\text { キャッサバ } \\
\text { 澱粉入り }\end{array}$ \\
\hline 積 $\left(\mathrm{cm}^{2}\right): A$ & 27 & 26 & 38 & 39 & 62 \\
\hline 伸㖘抵抗 $(B U)$ : $R$ & 267 & 250 & 345 & 283 & 550 \\
\hline 伸張度 $(\mathrm{mm}): \mathrm{E}$ & 115 & 129 & 106 & 135 & 118 \\
\hline 形状係数：R/E & 2.3 & 1.9 & 3.3 & 2.1 & 4.7 \\
\hline
\end{tabular}


ペーストの割合が異なるため，餅が䤄化し物情が変化し ていく際にこれらの因子が大きく影響するるのと考光ら れる。今後槍生地の微細構造と構成成分について検討を 進める予定である。 また，スタンプ式によるワキシーコ ーソ执よびキャッサバ激粉添加餅の物性は，添加した測 粉の性質により大さく影響されることが認められた。そ して冷蔵保存により糯米 $100 \%$ 餅より添加物入餅の汪 うが剪断強度が增加するのは，晸粉ペーストの割合が多 くなったためであると考える。

以上より，小ままで経験的に評洒されてきた飭の物性 が機器測定により客観的な数值として比較検討すること ができるとともに，添加物による新しい䬼としての知見 を得ることができた。

\section{要約}

餅の理化学的性質を明らかにする目的で，搗き方別特 よび添加物別餅を調製し，走查型電子顕微鏡を用いて組 織を観察するとともに，糊化度と機器による物性の測定 を行った。

3 種の調製法のらら，杵搗き特よびスタンプ式では， 餅の中に米粒組織の残存部分が多かった。ミキサー式で は，米粒組織が細かく研かれ，ペースト状の部分の多い ことが観察された. $\beta$ ーアミラーゼ・プルラナーゼ法によ り餻の保存過程の糊化度の变化を測定したところ，すず かな低下が認められた。

レオロメーター・ミートシャーメーターおよびエクス テンソグラフルよる搗さ方別餅の物性では, スタンプ式 餅がすっと硬く，伸長抵抗が大であった，杵搗き式餅 は剪断強度がもっとも大きく，ミキサー式餙はもっとも 柔らかく，剪率強度は小さく，伸長抵抗も小さかった。

糯米 $100 \%$ 餅と，ワキシーコーン怙よびキャッサバ 涉粉を各 $30 \%$ 添加した 3 種の餅の物性では，ワキシー コーン澱粉添加により，菜らかく，剪断強度が小さくな るが，キャッサバ浿粉添加により，餅の便さと粘りの增 加することが認められた。

本稿を終えるにあたり，澱羒試料をご提供ください充 した日本食品化工侏和よび味の素㑣に感謝致しますとと もに，機器測定にご便宜を括与えくださいました社日本

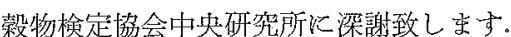

\section{文献}

1）二國二郎：自然 (中央公諭社)，2，14-21（1948）.
2）日東製菓烟編集：扣多ちの本，食品出版社，東京， p. 66 (1983)

3）斎藤昭三，谷地田武男，石井修一，有坂将美，中島 幸一：新潟食研報，11，85-90（1970）。

4）谷坞田武男, 中島幸一, 斎㻮昭三：新鼬食研報， 11 , 91-93 (1970).

5）窑藤昭三，谷地田武男，若林 昭，中島幸一，細川 平太郎：新潟食研報，11，95-98（1970）。

6）斎藤昭三，有坂将美，不井修一：新潟食研報， 13 , 49-56 (1974)。

7）斎藤炤三，有坂将美，石井修一，谷地田武男，中島 幸一：新潟食砟報，13，57-67（1974）。

8）斎藤昭三，江川和徳，石井修一，有坂将美，谷地田 武男，中村幸一：新潟食研報，14，53-58（1977）。

9）斎藤昭三，石井修一，有坂将美，江川和徳：新潟食 研報，15，39-45（1978）。

10）斎藤昭三，谷地田武男，石井修一，有坡将美，江川 和徳，中村幸一：新潟食研報，18，39-42（1981）。

11）柳瀬 綮，遠藤 勲，奥野元子：食総研報，42，19 (1983)

12）柳瀨 肇，大坪研一，橋本勝彦：食総研報，45，18 (1984)

13）桐㴊泓雄：食品開発，11，35-39（1976）。

14）斉藤昭三，池山八郎，福場博保：新潟食研報，9, 63-66 (1966).

15）斎藤昭三，馬場 操：新潟食吥報，9，67-70 (1966)。

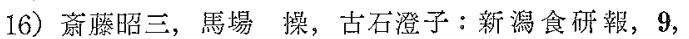
71-75 (1966).

17）斎藤昭三，馬場 操，古石澄子：新潟食研報，9, 77-83 (1966)

18）池山八郎，斎藤昭三：新鼬食研報，10, 25-28(1968)。

19）馬場 操，斎藤眧三：新潟食研報，10，29-30(1968)。

20）䭴踼 操，斎藤昭三：新潟食研報，10，31-33(1968).

21) H. Horiuchi: Agric. Biol. Chem., 44, 1231-1235 (1980).

22）堣内久弥：農化， 54, 241-245（1980).

23）堀内久弥：日食工誌，33，38-43（1986）.

24) A. KAWABATA, S. SAWAyAmA, N. NAGASHima, R. R. del RosArio and M. NAKAMURA: J.Jpn. Soc. Starch Sci., 31, 4, 224-232 (1984).

25）永島伸浩, 川端晶子, 中村迩德：第 39 回日本栄養。 食糧学会緿会講演要旨集，p. 157，東京 (1985).

26) 哭田茂久: 食品分析法（日本食品工業学会食品分析 法編集委員会編)，光琳，東京，p.619（1982）。

27）福場博保：米と飯の科学（全国米穀配給協会編）, 不二出版，東京，p.53 (1977).

28）貝沼圭二，松永焼子，板川正秀，小性昭一：聲粉科 学, 28, 235-240 (1981).

29) 柴田茂久：食品分析法（日本食品工業学会食品分析 法編集委貣会編)，光琳，東京，p.626（1982）。

30）江川和徳, 石井修一, 吉井洋一, 谷地田武男: 日本食品 工業学会第 31 回大会講演集，p. 38，茨城（1984）.

31) 斎藤昭三：日本食品工業学会第 17 回大会講演集, p. 50，茨城（1969）。 